\title{
A Cross-Sectional Study of 0.6 Million Children with Attention-Deficit/Hyperactivity Disorder in the United States
}

\author{
Irene Rethemiotaki ${ }^{10}$ \\ ${ }^{1}$ School of Production Engineering and Management, Technical \\ University of Crete, Chania, Greece \\ J Child Sci 2020;10:e97-e103.
}

\author{
Address for correspondence Irene Rethemiotaki, MSc, School of \\ Production Engineering and Management, Technical University of \\ Crete, Kounoupidiana, GR-73100 Chania, Greece \\ (e-mail: eirinireth@yahoo.gr).
}

\begin{abstract}
Keywords

- ADHD

- prognostic factors

- socioeconomic factors

Attention-deficit hyperactivity disorder (ADHD) is an increasingly recognized chronic neurodevelopmental disorder. This work aims at studying the prevalence and clinical characteristics of children with ADHD in the United States in the period between 2009 and 2018. Data from the National Health Interview Survey were analyzed by univariate and multivariate statistics to assess the role of socioeconomic factors in the development of ADHD. It has been studied 615,608 children, 51.2\% male and 48.7\% female. The prevalence of ADHD was $9.13 \%$, with males predominating over females. The number of children with ADHD increased from 2009 to 2018 by $14.8 \%$. As specified by multiple logistic regression analysis, males (odds ratio [OR] 2.38) who have neither mother nor father (OR 1.76) are twice as likely to have ADHD compared with their peers. In addition, family income (OR 1.40) and parent's education (OR 1.12) were significantly associated with ADHD. It has been highlighted the significance of deprivation of both family and financial comfort as primary indicators for ADHD in children. Moreover, children with ADHD were more likely to be males in the age group of 12 to 17 .
\end{abstract}

\section{Introduction}

Attention-deficit hyperactivity disorder (ADHD) is a chronic neurodevelopmental disorder in which children cannot handle their behavior due to difficulty in processing neural stimuli, followed by high activity levels. ${ }^{1}$ Inattention, impulsivity, and hyperactivity are some of the symptoms that the child is faced with..$^{2-4}$ The prevalence of ADHD ranges from 1 to $20 \%$ among children and adolescents worldwide. ${ }^{5-9}$ The knowledge of the prevalence of ADHD among children is of paramount importance for further response scheduling, resource allocation, training, and research. ${ }^{10}$

Low socioeconomic status (SES) has been linked not only to poor physical health but also to impaired mental health in childhood. ${ }^{11-19}$ In particular, children from low socioeconomic backgrounds are 1.18 to 3.34 times more likely to have mental health problems than their peers. ${ }^{19}$ The association between ADHD and SES appears to be complex because

received

May 31, 2020

accepted

August 7, 2020
DOI https://doi.org/

10.1055/s-0040-1716715. ISSN 2474-5871. symptoms are associated with interactions between genes and the environment during development. ${ }^{20}$ Other proposed factors that could be involved include maternal mental health, ${ }^{21}$ substance abuse, ${ }^{22}$ as well as the parent's involvement in the upbringing of their child. ${ }^{23}$

It is of utmost importance to acknowledge the seriousness of ADHD in children, and the knowledge of underlying factors that lead children to ADHD. For this purpose, this work studied ADHD in the United States during the period 2009 to 2018 with the aim to find statistically significant socioeconomic indicators for this type of disorder.

\section{Methods}

The data used in this work originate from the National Health Interview Survey (NHIS) data set ${ }^{24}$ and cover the period 2009 to 2018. The target population for NHIS is the civilian
Copyright $\odot 2020$ Georg Thieme Verlag License terms
KG Stuttgart · New York 
noninstitutionalized population of the United States. NHIS data are collected through personal household interviews. The main objective of NHIS is to monitor the health of the U.S. population through the collection and analysis of data on a broad range of health topics. Each year, a representative sample of households across the country is selected for NHIS using a multistage cluster sample design. Trained interviewers from the U.S. Census Bureau visit each selected household and administer the NHIS in person. To identify children with ADHD, each household was asked to answer the question: "Has a doctor or other health professional ever told you that [child's name] had ADHD or attention deficit disorder?" Statistical methods were chi-square test for categorical variables and one-way analysis of variance for continues variables to check the hypothesis that the prevalence of ADHD was not associated with socioeconomic characteristics (gender, age, race, origin, parent's education, family income, poverty status, health insurance coverage, current health status, family structure, place of residence, and region). Factors associated with ADHD were identified by multiple logistic regression analysis. Children with ADHD (case group) were compared with a matched cohort of children without this condition (control group). Factors associated with ADHD were represented using the odds ratio (OR) and 95\% confidence intervals, and a $p$-value of $<0.05$ was considered statistically significant. Particularly, the OR has been used to compare the relative odds of occurrence of the outcome of interest (children with ADHD), given exposure to the variable of interest (specific socioeconomic characteristics of children). ${ }^{25}$ The study was performed using IBM SPSS 25 software package for Windows.
All procedures performed were in accordance with the ethical standards of the institutional and/or national research committee and with the 1964 Helsinki Declaration and its later amendments or comparable ethical standards.

\section{Results}

Participants of this study were $615,608,51.2 \%$ males and $48.7 \%$ females. Moreover, $13.5 \%$ of the participants were 0 to 4 years old, $46.5 \%$ of them were 5 to 11 years old, and finally, $40.1 \%$ of them were 12 to 17 years old. The number of children and adolescents with ADHD was 56,252. As shown in -Table 1, ADHD was more frequent in males, in the age group of 12 to 17 years, and in Caucasians. Most children with ADHD had parents with high education-more than a high school diploma (69.2\%)-and excellent or very good health status (72.1\%). Moreover, most families whose children have ADHD were not poor (51.4\%), with a family income of $\$ 35,000$ or more $(38.4 \%)$ and private health insurance coverage (47.5\%). Finally, most children with ADHD had both mother and father as family structure (57.5\%) and live in southern U.S. (43.1\%), in large metropolitan areas with a population size of one million or more (47.3\%).

Most children in the control group were females, in the age group of 5 to 11, and Caucasians. Most children of the control group had parents with high education-more than a high school diploma (69.5\%)-and excellent or very good health status (84.5\%). Moreover, most families from the control group were not poor (57.8\%), with a family income of $\$ 35,000$ or more (41.4\%) and private health insurance coverage (55.9\%). Finally, most children from the control group had both mother

Table 1 Chi-square and one-way ANOVA test

\begin{tabular}{|c|c|c|c|c|}
\hline \multicolumn{2}{|c|}{ Characteristics of children with ADHD: United States 2009-2018 } & \multirow{2}{*}{$\begin{array}{c}\text { Children } \\
\text { with ADHD }\end{array}$} & \multirow[t]{2}{*}{ Percentages } & \multirow{2}{*}{$\begin{array}{c}p \text {-Value } \\
<0.05\end{array}$} \\
\hline Gender & & & & \\
\hline & Male & 39,308 & $69.9 \%$ & \\
\hline & Female & 16,944 & $30.1 \%$ & \\
\hline \multirow[t]{4}{*}{ Age } & & & & $<0.05$ \\
\hline & $3-4$ & 1,228 & $2.2 \%$ & \\
\hline & $5-11$ & 24,280 & $43.2 \%$ & \\
\hline & $12-17$ & 30,746 & $54.7 \%$ & \\
\hline \multirow[t]{4}{*}{ Race } & & & & $<0.05$ \\
\hline & White & 42,627 & $81.4 \%$ & \\
\hline & Black or African American & 9,104 & $17.4 \%$ & \\
\hline & Asian & 627 & $1.2 \%$ & \\
\hline \multirow[t]{6}{*}{ Origin } & & & & $<0.05$ \\
\hline & Hispanic or Latino & 8,491 & $8.1 \%$ & \\
\hline & Mexican or Mexican American & 4,930 & $4.7 \%$ & \\
\hline & Not Hispanic or Latino & 47,762 & $45.4 \%$ & \\
\hline & White. single race & 35,315 & $33.6 \%$ & \\
\hline & Black or African American. single race & 8,598 & $8.2 \%$ & \\
\hline
\end{tabular}


Table 1 (Continued)

\begin{tabular}{|c|c|c|c|c|}
\hline \multicolumn{2}{|c|}{ Characteristics of children with ADHD: United States 2009-2018 } & \multirow{2}{*}{$\begin{array}{c}\text { Children } \\
\text { with ADHD }\end{array}$} & \multirow[t]{2}{*}{ Percentages } & \multirow{2}{*}{$\begin{array}{c}p \text {-Value } \\
<0.05\end{array}$} \\
\hline Parent's education & & & & \\
\hline & Less than a high school diploma & 5,333 & $10.1 \%$ & \\
\hline & High school diploma & 10,972 & $20.7 \%$ & \\
\hline & More than a high school diploma & 36,603 & $69.2 \%$ & \\
\hline \multirow[t]{7}{*}{ Family income } & & & & $<0.05$ \\
\hline & Less than $\$ 35,000$ & 19,888 & $23.1 \%$ & \\
\hline & $\$ 35,000$ or more & 33,065 & $38.4 \%$ & \\
\hline & $\$ 35,000-\$ 49,999$ & 6,438 & $7.5 \%$ & \\
\hline & $\$ 50,000-\$ 74,999$ & 8,078 & $9.4 \%$ & \\
\hline & $\$ 75,000-\$ 99,999$ & 5,411 & $6.3 \%$ & \\
\hline & $\$ 100,000$ or more & 13,137 & $15.3 \%$ & \\
\hline \multirow[t]{4}{*}{ Poverty status } & & & & $<0.05$ \\
\hline & Poor & 13,522 & $25.1 \%$ & \\
\hline & Near poor & 12,677 & $23.5 \%$ & \\
\hline & Not poor & 27,666 & $51.4 \%$ & \\
\hline \multirow[t]{5}{*}{ Health insurance coverage } & & & & $<0.05$ \\
\hline & Private & 26,593 & $47.5 \%$ & \\
\hline & Medicaid & 25,535 & $45.6 \%$ & \\
\hline & Other coverage & 1,671 & $3.0 \%$ & \\
\hline & Uninsured & 2,238 & $4.0 \%$ & \\
\hline \multirow[t]{4}{*}{ Current health status } & & & & $<0.05$ \\
\hline & Excellent or very good & 40,552 & $72.1 \%$ & \\
\hline & Good & 12,670 & $22.5 \%$ & \\
\hline & Fair or poor & 3,034 & $5.4 \%$ & \\
\hline \multirow[t]{5}{*}{ Family structure } & & & & $<0.05$ \\
\hline & Mother and father & 32,334 & $57.5 \%$ & \\
\hline & Mother, no father & 18,239 & $32.4 \%$ & \\
\hline & Father, no mother & 2,418 & $4.3 \%$ & \\
\hline & Neither mother nor father & 3,262 & $5.8 \%$ & \\
\hline Place of residence & & & & $<0.05$ \\
\hline \multirow[t]{3}{*}{ MSA (metropolitan statistical area) } & Large MSA (population size 1 million or more) & 26,611 & $47.3 \%$ & \\
\hline & Small MSA (less than 1 million) & 19,578 & $34.8 \%$ & \\
\hline & Not in MSA & 10,064 & $17.9 \%$ & \\
\hline \multirow[t]{5}{*}{ Region } & & & & $<0.05$ \\
\hline & Northeast & 9,023 & $16.0 \%$ & \\
\hline & Midwest & 14,123 & $25.1 \%$ & \\
\hline & South & 24,242 & $43.1 \%$ & \\
\hline & West & 8,869 & $15.8 \%$ & \\
\hline
\end{tabular}

Abbreviations: ADHD, attention-deficit hyperactivity disorder; ANOVA, analysis of variance.

and father as family structure (69.5\%) and they live south (36.4\%), in a large metropolitan statistical area with a population size of one million or more (58.0\%).

- Table 2 represents the multiple logistic regression analysis with the ORs with the aim of finding predictors for
ADHD. As can be seen in - Table 2, all prognostic factors were statistically significant $(p<0.05)$. Based on multiple logistic regressions, children who were more likely to have ADHD were black or African Americans (OR 5.4), males (OR 2.38), and in the age group of 12 to 17 (OR 1.0), with parents having 
A Cross-Sectional Study of 0.6 Million Children with Attention-Deficit/Hyperactivity Disorder in the

Table 2 Statistically significant predictors of ADHD in children using multivariate logistic regression

\begin{tabular}{|c|c|c|c|c|c|}
\hline \multicolumn{2}{|c|}{$\begin{array}{c}\text { Socioeconomic characteristics of children: } \\
\text { United States } 2009-2018\end{array}$} & \multirow[t]{2}{*}{ Patients } & \multirow[t]{2}{*}{ Controls } & \multirow[t]{2}{*}{$\begin{array}{l}\text { Odds ratio } \\
(95 \% \mathrm{Cl})\end{array}$} & \multirow{2}{*}{$\begin{array}{l}p \text {-Value } \\
<0.05\end{array}$} \\
\hline Gender & & & & & \\
\hline & Male & 39,308 & 276,048 & $2.38(2.33-2.42)$ & \\
\hline & Female & 16,944 & 283,308 & 1.0 (ref) & \\
\hline \multirow[t]{4}{*}{ Age } & & & & & $<0.05$ \\
\hline & $3-4$ & 1,228 & 82,016 & $0.10(0.10-0.11)$ & \\
\hline & $5-11$ & 24,280 & 262,956 & $0.65(0.64-0.66)$ & \\
\hline & $12-17$ & 30,746 & 216,951 & 1.0 (ref) & \\
\hline \multirow[t]{4}{*}{ Race } & & & & & $<0.05$ \\
\hline & White & 42,627 & 416,541 & $4.98(4.6-5.4)$ & \\
\hline & Black or African American & 9,104 & 82,076 & $5.4(4.98-5.86)$ & \\
\hline & Asian & 627 & 30,557 & 1.0 (ref) & \\
\hline \multirow[t]{6}{*}{ Origin } & & & & & $<0.05$ \\
\hline & Hispanic or Latino & 8,491 & 138,513 & $0.54(0.52-0.56)$ & \\
\hline & Mexican or Mexican American & 4,930 & 94,190 & $0.46(0.44-0.48)$ & \\
\hline & Not Hispanic or Latino & 47,762 & 423,414 & $1.0(0.97-1.0)$ & \\
\hline & White single race & 35,315 & 293,397 & $1.01(1.04-1.09)$ & \\
\hline & $\begin{array}{l}\text { Black or African American, } \\
\text { single race }\end{array}$ & 8,598 & 76,337 & 1.0 (ref) & \\
\hline \multirow[t]{4}{*}{ Parent's education } & & & & & $<0.05$ \\
\hline & Less than a high school diploma & 5,333 & 65,515 & $0.83(0.81-0.86)$ & \\
\hline & High school diploma & 10,972 & 100,341 & $1.12(1.10-1.15)$ & \\
\hline & More than a high school diploma & 36,603 & 377,321 & 1.0 (ref) & \\
\hline \multirow[t]{7}{*}{ Family income } & & & & & $<0.05$ \\
\hline & Less than $\$ 35,000$ & 19,888 & 152,705 & $1.4(1.4-1.5)$ & \\
\hline & $\$ 35,000$ or more & 33,065 & 365,674 & $1.02(1.00-1.04)$ & \\
\hline & $\$ 35,000-\$ 49,999$ & 6,438 & 63,897 & $1.14(1.10-1.17)$ & \\
\hline & $\$ 50,000-\$ 74,999$ & 8,078 & 87,394 & $1.04(1.01-1.07)$ & \\
\hline & $\$ 75,000-\$ 99,999$ & 5,411 & 65,711 & $0.93(0.90-0.96)$ & \\
\hline & $\$ 100,000$ or more & 13,137 & 148,677 & 1.0 (ref) & \\
\hline \multirow[t]{4}{*}{ Poverty status } & & & & & $<0.05$ \\
\hline & Poor & 13,522 & 103,020 & $1.45(1.42-1.48)$ & \\
\hline & Near poor & 12,677 & 120,095 & $1.16(1.14-1.19)$ & \\
\hline & Not poor & 27,666 & 305,974 & 1.0 (ref) & \\
\hline \multirow[t]{5}{*}{ Health insurance coverage } & & & & & $<0.05$ \\
\hline & Private & 26,593 & 313,087 & $1.4(1.3-1.4)$ & \\
\hline & Medicaid & 25,535 & 194,357 & $2.2(2.1-2.3)$ & \\
\hline & Other coverage & 1,671 & 14,770 & $1.89(1.77-2.0)$ & \\
\hline & Uninsured & 2,238 & 37,480 & 1.0 (ref) & \\
\hline \multirow[t]{4}{*}{ Current health status } & & & & & $<0.05$ \\
\hline & Excellent or very good & 40,552 & 474,701 & $0.26(0.25-0.27)$ & \\
\hline & Good & 12,670 & 77,857 & $0.49(0.47-0.52)$ & \\
\hline & Fair or poor & 3,034 & 9,266 & 1.0 (ref) & \\
\hline
\end{tabular}


Table 2 (Continued)

\begin{tabular}{|c|c|c|c|c|c|}
\hline \multicolumn{2}{|c|}{$\begin{array}{c}\text { Socioeconomic characteristics of children: } \\
\text { United States } 2009-2018\end{array}$} & \multirow[t]{2}{*}{ Patients } & \multirow[t]{2}{*}{ Controls } & \multirow[t]{2}{*}{$\begin{array}{c}\text { Odds ratio } \\
(95 \% \mathrm{Cl})\end{array}$} & \multirow{2}{*}{$\begin{array}{l}p \text {-Value } \\
<0.05\end{array}$} \\
\hline Family structure & & & & & \\
\hline & Neither mother nor father & 3,262 & 17,000 & $1.76(1.66-1.86)$ & \\
\hline & Mother, no father & 18,239 & 132,207 & $0.76(0.72-0.79)$ & \\
\hline & Father, no mother & 2,418 & 22,208 & $1.26(1.21-1.32)$ & \\
\hline & Mother and father & 32,334 & 390,514 & 1.0 (ref) & \\
\hline Place of residence & & & & & $<0.05$ \\
\hline \multirow[t]{3}{*}{ MSA (metropolitan statistical area) } & $\begin{array}{l}\text { Large MSA (population } \\
\text { size } 1 \text { million or more) }\end{array}$ & 26,611 & 311,997 & $0.6(0.58-0.61)$ & \\
\hline & Small MSA (less than 1 million) & 19,578 & 155,337 & $0.9(0.86-0.91)$ & \\
\hline & Not in MSA & 10,064 & 70,927 & 1.0 (ref) & \\
\hline \multirow[t]{5}{*}{ Region } & & & & & $<0.05$ \\
\hline & Northeast & 9,023 & 91,913 & $1.54(1.5-1.6)$ & \\
\hline & Midwest & 14,123 & 125,650 & $1.77(1.72-1.82)$ & \\
\hline & South & 24,242 & 204,506 & $1.86(1.82-1.91)$ & \\
\hline & West & 8,869 & 139,856 & 1.0 (ref) & \\
\hline
\end{tabular}

Abbreviations: ADHD, attention-deficit hyperactivity disorder; $\mathrm{Cl}$, confidence interval.

“high school diploma” as education status (OR 1.12). Moreover, children whose parents had a family income less than $\$ 35,000$ (OR 1.4) and Medicaid health insurance coverage (OR 2.2) were twofold more likely to have ADHD. In addition, poor children (OR 1.62), with "fair or poor" current health status (OR 1.00), who live south (OR 1.86), "not in a metropolitan statistical area" (OR 1.00), were more likely to have ADHD. Finally, children who had neither mother nor father were also more likely to have ADHD (OR 1.76).

-Fig. 1 represents the trend in ADHD in children during the years 2009 to 2018 in the United States. The number of children with ADHD increased from 2009 to 2018 by $14.8 \%$. Moreover, the prevalence of ADHD in this decade was 9.13\%. - Fig. 2 represents the prognostic factors with the ORs for ADHD. As can be seen, ethnicity ranks first, followed by gender, health insurance coverage, region, and family structure.

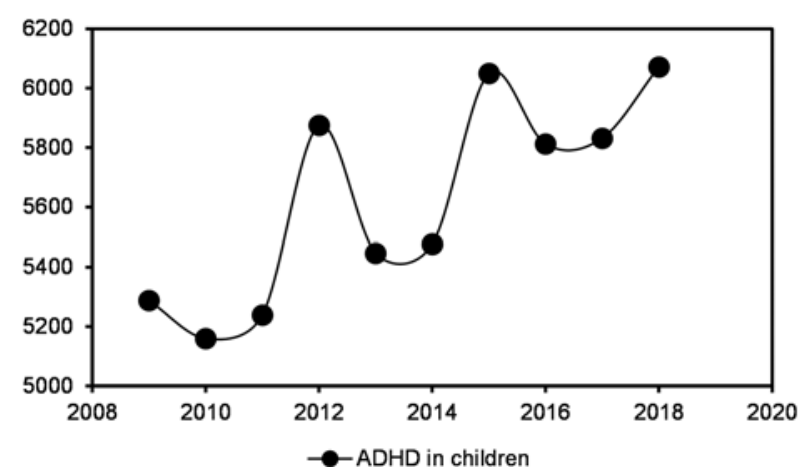

Fig. 1 Trend in attention-deficit hyperactivity disorder (ADHD) during the years 2009 to 2018 in the United States.

\section{Discussion}

The number of children diagnosed with ADHD in the United States during the years 2009 to 2018 increased at an alarming rate of $14.8 \%$. Children who had neither mother nor father were twice as likely to have ADHD. This can be explained by the fact that the lack of parents reflects problems in the psychopathology of the child. These results are in agreement with prior studies, in which ADHD was linked to the lack of parent's involvement in the upbringing of their child. ${ }^{26}$

Additionally, family income and poverty status play a key role in the occurrence of this type of disorder. Children living in a poor financial situation and low SES were more likely to have ADHD. The results of this study are in agreement with prior studies, in which it has been reported that although ADHD is highly heritable, symptoms are associated with interactions between genes and the environment during development such as low SES and chaos (household disorganization). ${ }^{27}$ It has also been found that socioeconomic disadvantage was associated with emotional and conduct problems in children but neither home environment nor parenting attenuated this association, indicating the decisive role of SES in the child's psychopathology. ${ }^{28}$

The importance of this study lies in the interaction between multiple socioeconomic variables and ADHD, which reflects the complexity and multidimensional nature of deprivation, as well as the various roles of these dimensions during the course of life, which in turn reflects the longest gestation period for ADHD. Deprivation has been linked to stress, which in turn influences human behavior and health. More specifically, stressors in early life are responsible for the production of cortisol, a hormone that peaks in response 


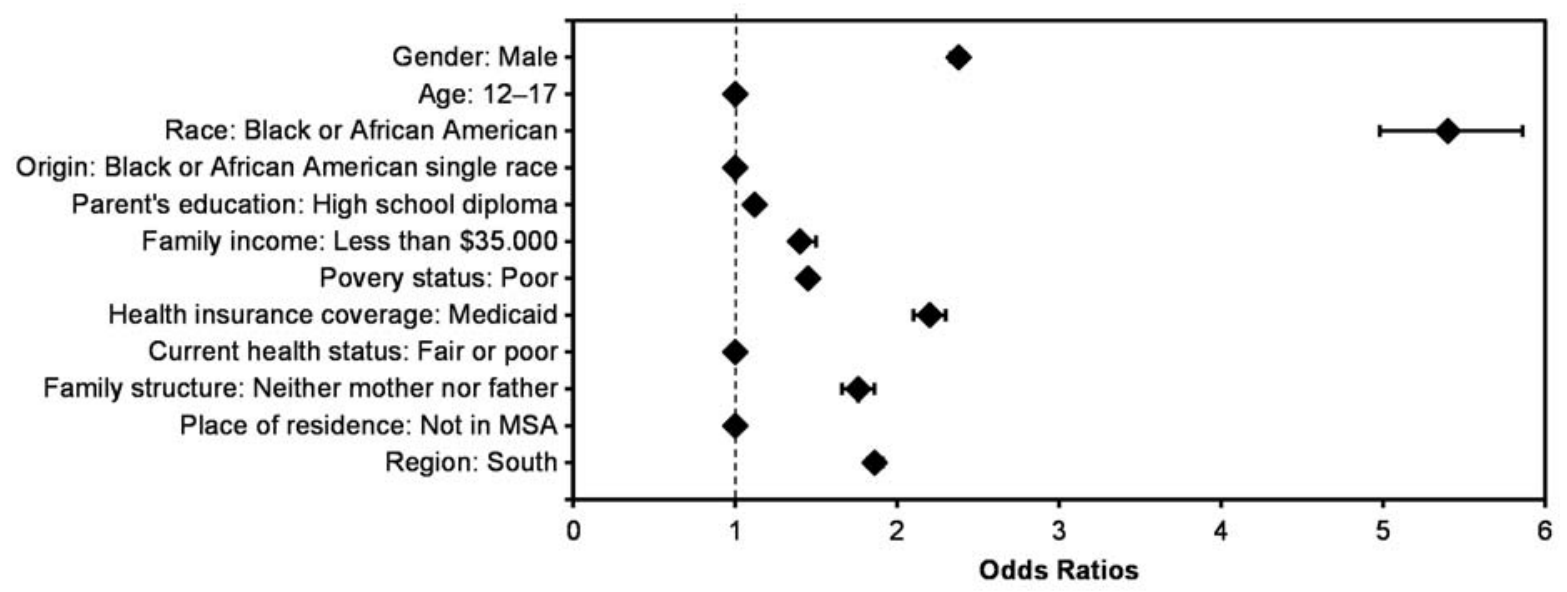

Fig. 2 Prognostic factors with the odds ratios for attention-deficit hyperactivity disorder (ADHD).

to stressful experiences, and has not only immunological effects but also social and behavioral consequences. ${ }^{29,30}$

One limitation of the present study is that data were collected through personal household interviews. Nondisclosure of a characteristic of the child by participants is possible due to memory and/or social bias. Another limitation of the study is that multiple logistic regression analysis does not establish causality between variables.

\section{Conclusion}

The results of this work explain the significance of deprivation (of family and financial comfort) as the main prognostic factor for ADHD. Moreover, children with ADHD are more likely to be black or African American, males in the age group of 12 to 17 .

\section{Conflict of Interest \\ None declared.}

\section{References}

1 Gallo EF, Posner J. Moving towards causality in attention-deficit hyperactivity disorder: overview of neural and genetic mechanisms. Lancet Psychiatry 2016;3(06):555-567

2 Thapar A, Cooper M. Attention deficit hyperactivity disorder. Lancet 2016;387(10024):1240-1250

3 American Psychiatric Association. Diagnostic and Statistical Manual of Mental Diseases (DSM-IV). 4th ed. Washington: American Psychiatric Publishing; 1994:873

4 World Health Organization (WHO). The ICD-10 Classification of Mental and Behavioral Disorders: Diagnostic Criteria for Research; 1993

5 Meltzer H, Gatward R, Goodman R, Ford T. Mental health of children and adolescents in Great Britain. Int Rev Psychiatry 2003;15(1-2):185-187

6 Polanczyk G, de Lima MS, Horta BL, Biederman J, Rohde LA. The worldwide prevalence of ADHD: a systematic review and metaregression analysis. Am J Psychiatry 2007;164(06):942-948

$7 \mathrm{Hr} \mathrm{B}$. The Diagnostic Classification, Epidemiology and CrossCultural Validity of ADHD, in Attention Deficit Hyperactivity Disorder: State of the Science: Best Practices. Princeton, NJ: Civic Research Institute; 2002
8 Faraone SV, Sergeant J, Gillberg C, Biederman J. The worldwide prevalence of ADHD: is it an American condition? World Psychiatry $2003 ; 2(02): 104-113$

9 Willcutt EG. The prevalence of DSM-IV attention-deficit/hyperactivity disorder: a meta-analytic review. Neurotherapeutics 2012;9(03):490-499

10 Singh I. Beyond polemics: science and ethics of ADHD. Nat Rev Neurosci 2008;9(12):957-964

11 Spencer N. Poverty and Child Health. 2nd ed. Oxford: Radcliffe Medical Press Ltd; 2000

12 Schneiders J, Drukker M, van der Ende J, Verhulst FC, van Os J, Nicolson NA. Neighbourhood socioeconomic disadvantage and behavioural problems from late childhood into early adolescence. J Epidemiol Community Health 2003;57(09):699-703

13 Kalff AC, Kroes M, Vles JS, et al. Neighbourhood level and individual level SES effects on child problem behaviour: a multilevel analysis. J Epidemiol Community Health 2001;55(04): 246-250

14 Bøe T, Øverland S, Lundervold AJ, Hysing M. Socioeconomic status and children's mental health: results from the Bergen Child Study. Soc Psychiatry Psychiatr Epidemiol 2012;47(10):1557-1566

15 Keyes KM, March D, Link BG, Chilcoat HD, Susser E. Do socioeconomic gradients in smoking emerge differently across time by gender? Implications for the tobacco epidemic from a pregnancy cohort in California, USA. Soc Sci Med 2013;76(01):101-106

16 Graham H. Building an inter-disciplinary science of health inequalities: the example of lifecourse research. Soc Sci Med 2002;55(11):2005-2016

17 Aber JL, Bennett NG, Conley DC, Li J. The effects of poverty on child health and development. Annu Rev Public Health 1997;18(01): 463-483

18 Kiernan KE, Mensah FK. Poverty, maternal depression, family status and children's cognitive and behavioural development in early childhood: a longitudinal study. J Soc Policy 2009;38(04): 569-588

19 Reiss F. Socioeconomic inequalities and mental health problems in children and adolescents: a systematic review. Soc Sci Med 2013;90:24-31

20 Russell G, Ford T, Rosenberg R, Kelly S. The association of attention deficit hyperactivity disorder with socioeconomic disadvantage: alternative explanations and evidence. J Child Psychol Psychiatry 2014;55(05):436-445

21 Sagiv SK, Epstein JN, Bellinger DC, Korrick SA. Pre- and postnatal risk factors for ADHD in a nonclinical pediatric population. J Atten Disord 2013;17(01):47-57

22 Lingineni RK, Biswas S, Ahmad N, Jackson BE, Bae S, Singh KP. Factors associated with attention deficit/hyperactivity disorder 
among US children: results from a national survey. BMC Pediatr 2012;12(01):50

23 Gonzalez-DeHass AR, Willems PP, Holbein MFD. Examining the relationship between parental involvement and student motivation. Educ Psychol Rev 2005;17(02):99-123

24 National Center for Health Statistics Data file documentation: National Health Interview Survey. 2016. Available at: https:// www.cdc.gov/nchs/nhis.htm. Accessed August 26, 2020

25 Szumilas M. Explaining odds ratios [published correction appears in J Can Acad Child Adolesc Psychiatry. 2015 Winter;24(1):58]. J Can Acad Child Adolesc Psychiatry 2010;19(03):227-229

26 Montes G, Montes SA. Parental involvement of parents of children with ADHD: a first population study. J Atten Disord 2020; •.o:1087054720911099
27 Gould KL, Coventry WL, Olson RK, Byrne B. Gene-environment interactions in ADHD: the roles of SES and chaos. J Abnorm Child Psychol 2018;46(02):251-263

28 Flouri E, Midouhas E, Ruddy A, Moulton V. The role of socioeconomic disadvantage in the development of comorbid emotional and conduct problems in children with ADHD. Eur Child Adolesc Psychiatry 2017;26(06):723-732

29 Gustafsson PE, Janlert U, Theorell T, Hammarström A. Life-course socioeconomic trajectories and diurnal cortisol regulation in adulthood. Psychoneuroendocrinology 2010;35(04):613-623

30 Hajat A, Diez-Roux A, Franklin TG, et al. Socioeconomic and race/ethnic differences in daily salivary cortisol profiles: the multi-ethnic study of atherosclerosis. Psychoneuroendocrinology 2010;35(06):932-943 